\title{
Relative Efficiency of Zinc-Coated Urea and Soil and Foliar Application of Zinc Sulphate on Yield, Nitrogen, Phosphorus, Potassium, Zinc and Iron Biofortification in Grains and Uptake by Basmati Rice (Oryza sativa L.)
}

\author{
Yashbir Singh Shivay ${ }^{1}$, Rajendra Prasad ${ }^{1}$, Rajiv Kumar Singh ${ }^{2,3} \&$ Madan Pal $^{1}$ \\ ${ }^{1}$ Division of Agronomy, Indian Agricultural Research Institute, New Delhi, India \\ ${ }^{2}$ Krishi Vigyan Kendra, Aligarh of Chander Shekhar Azad University of Agriculture \& Technology, Kanpur, \\ India \\ ${ }^{3}$ Directorate of Seed Research, Village Kushmaur, Post Office, NBAIM, District Mau, Uttar Pradesh, India \\ Correspondence: Yashbir Singh Shivay, Division of Agronomy, Indian Agricultural Research Institute, New \\ Delhi 110 012, India. Tel: 91-986-833-7578. E-mail: ysshivay@hotmail.com
}

Received: October 10, 2014 Accepted: December 16, 2014 Online Published: January 15, 2015

doi:10.5539/jas.v7n2p161 URL: http://dx.doi.org/10.5539/jas.v7n2p161

\begin{abstract}
Two on-farm trials conducted one each in Aligarh and Meerut districts of the state of Uttar Pradesh, India on zinc (Zn) deficient soils during the rainy season (July-October) showed that $\mathrm{Zn}$ application increased not only $\mathrm{Zn}$ concentration and uptake by rice but also increased protein content of rice kernels and concentrations of $\mathrm{Fe}, \mathrm{N}, \mathrm{P}$ and $\mathrm{K}$ due to the overall improvement in crop growth. Foliar application of $\mathrm{Zn}$ was better from the viewpoint of $\mathrm{Zn}$ biofortification of rice kernels; nevertheless much of the foliar applied $\mathrm{Zn}$ was retained in husk. Since, foliar application of $\mathrm{Zn}$ is made at a late stage of crop growth, hence it was not as effective as soil application in increasing yield attributes, yield and concentration and uptake of Fe, N, P and K in rice. This study brought out that adequate soil application of $\mathrm{Zn}$ sulphate followed by its foliar application is the best approach. $\mathrm{Zn}$ coated urea applying less than half the amount of $\mathrm{Zn}$ as applied through soil + foliar application was very close to it and is quite promising.
\end{abstract}

Keywords: basmati rice, ferti-fortification, nutrient concentrations and uptake, Zn fertilization

\section{Introduction}

Zinc $(\mathrm{Zn})$ is now recognised as the fourth major micronutrient deficiency in humans and comes after vitamin A, iron and iodine deficiencies (Bell \& Dell, 2008). Zn deficiency leads to diarrhoea and pneumonia in infants and children (Black et al., 2008; Graham, 2008) and is considered for responsible for childhood dwarfism (Hotz \& Brown, 2004). Zn plays an important role in production of protein and thus helps in wound healing, blood formation and growth and maintenance of tissue (Bell \& Dell, 2008).

Rice is staple food in South and Southeast Asia, where about $90 \%$ of it is grown and consumed. Polished rice contains only $13-15 \mathrm{mg} \mathrm{Zn} \mathrm{kg}^{-1}$ (Welch, 2005) and a rice based diet is thus likely to be deficient in $\mathrm{Zn}$ as compared to diet containing grain legumes and animal proteins, which are rich in $\mathrm{Zn}$ (Prasad, 2003). Asian, especially Indian soils are low in available Zn (Prasad, 2006; Singh, 2011) and this leads to production of low Zn containing rice. Keeping this in view, programmes such as HarvestPlus and Golden Rice are underway to develop rice varieties capable of producing grains denser in Zn, Fe and other micronutrients (Stein et al., 2007).

Our research at the Indian Agricultural Research Institute (IARI), New Delhi (Shivay et al., 2007; Shivay et al., 2008a, 2008b, 2008c; Shivay et al., 2010; Shivay \& Prasad, 2012; Shivay et al., 2013; Shivay \& Prasad, 2014) has shown that $\mathrm{Zn}$ concentration in rice, wheat, barley and corn grains can be easily increased by adequate $\mathrm{Zn}$ fertilization of crops and agronomic biofortification of cereals with $\mathrm{Zn}$ and $\mathrm{Fe}$, which are essential plant micronutrients (Prasad \& Power, 1997) is a faster and easier way for achieving the goal of obtaining cereal grains denser in $\mathrm{Zn}$. As a follow-up of our research at IARI, two on-farm field trials were therefore conducted to familiarize the farmers about the biofortification of rice grains with $\mathrm{Zn}$ and this paper reports the results of these on-farm trials. 


\section{Materials and Methods}

\subsection{Description of Study Area}

On-farm experiments were conducted at two different places. First on-farm trial was conducted at the Krishi Vigyan Kendra (KVK), Aligarh of Chandra Shekhar Azad University of Agriculture \& Technology, Kanpur, Uttar Pradesh, India during rainy season (July-October) of 2008 on a sandy clay loam soil (typic Ustochrept). The soil of experimental field had $133.7 \mathrm{~kg} \mathrm{ha}^{-1}$ alkaline permanganate oxidizable nitrogen $(\mathrm{N})$ (Subbiah \& Asija, 1956), $12.3 \mathrm{~kg} \mathrm{ha}^{-1}$ available phosphorus (P) (Olsen et al., 1954), $295.1 \mathrm{~kg} \mathrm{ha}^{-1} 1 \mathrm{~N}$ ammonium acetate exchangeable potassium (K) (Hanway \& Heidel, 1952) and 0.36\% organic carbon (C) (Walkley \& Black, 1934). The $\mathrm{pH}$ of soil was 8.5 (1: 2.5 soil and water ratio) (Prasad et al., 2006) and diethylene triamine penta acetic acid (DTPA) extractable $\mathrm{Zn}$ and Fe (Lindsay \& Norvell, 1978) in soil were 0.33 and $3.7 \mathrm{mg} \mathrm{kg}^{-1}$ of soil, respectively.

The second on-farm trial was conducted at Kulimanpur village of Meerut district, Uttar Pradesh, India during rainy season (July-October) of 2008 on a sandy loam soil. The soils of experimental field at second site had $127.3 \mathrm{~kg} \mathrm{ha}^{-1}$ alkaline permanganate oxidizable nitrogen (N) (Subbiah \& Asija, 1956), $14.7 \mathrm{~kg} \mathrm{ha}^{-1}$ available phosphorus (P) (Olsen et al., 1954), $278.9 \mathrm{~kg} \mathrm{ha}^{-1} 1 \mathrm{~N}$ ammonium acetate exchangeable potassium (K) (Hanway \& Heidel, 1952) and $0.35 \%$ organic carbon (C) (Walkley \& Black, 1934). The $\mathrm{pH}$ of soil was 8.2 (1:2.5 soil and water ratio) (Prasad et al., 2006) and diethylene triamine penta acetic acid (DTPA) extractable $\mathrm{Zn}$ and Fe (Lindsay \& Norvell, 1978) in soil were 0.35 and $4.9 \mathrm{mg} \mathrm{kg}^{-1}$ of soil, respectively. The critical level of DTPA extractable $\mathrm{Zn}$ for rice grown on alluvial soils in the rice-wheat belt of north India varies from $0.38-0.90 \mathrm{mg} \mathrm{kg}^{-1}$ soil (Takkar et al., 1997) and thus the response of Basmati rice to $\mathrm{Zn}$ application was expected on the experimental field.

\subsection{Experimental Treatments and Design}

The experiment was conducted in a randomized block design with six replications on both sites. The treatments were: check (control, no $\mathrm{Zn}$ ), $5 \mathrm{~kg} \mathrm{Zn} \mathrm{ha}^{-1}$ to soil as $\mathrm{Zn}$ sulpfate (soil), $1 \mathrm{~kg} \mathrm{Zn} \mathrm{ha}^{-1}$ as $\mathrm{Zn}$ suphate to foliage (foliar), $5 \mathrm{~kg} \mathrm{Zn} \mathrm{ha}^{-1}$ (soil) $+1 \mathrm{~kg} \mathrm{Zn} \mathrm{ha}^{-1}$ (foliar) and $2.83 \mathrm{~kg} \mathrm{Zn} \mathrm{ha}^{-1}$ through Zn-coated urea (soil).

\subsection{Application of Treatments and Fertilizers}

The experimental field was disk-ploughed twice, puddled three times with a puddler in standing water and levelled. At final puddling $26 \mathrm{~kg} \mathrm{P} \mathrm{ha}^{-1}$ as single superphosphate and $33 \mathrm{~kg} \mathrm{~K} \mathrm{ha}^{-1}$ as muriate of potash was broadcasted. Addition of $26 \mathrm{~kg} \mathrm{P}$ as single super phosphate also supplied $45 \mathrm{~kg} \mathrm{~S} h a^{-1}$ and takes care of S deficiency (if any). Nitrogen at $130 \mathrm{~kg} \mathrm{~N} \mathrm{ha}^{-1}$ as prilled urea or $\mathrm{Zn}$-coated urea (ZnCU) was band applied in two equal splits, half 10 days after transplanting (DAT) and the other half at panicle initiation (40 DAT). Thus, $\mathrm{Zn}$ in $\mathrm{ZnCU}$ was band applied. When applied at the site, $\mathrm{ZnCU}$ supplied $2.83 \mathrm{~kg} \mathrm{Zn} \mathrm{ha}^{-1}$ for the $1.0 \% \mathrm{Zn}$ coatings onto prilled urea. Foliar application of $\mathrm{Zn}$ was made at flowering and $0.5 \% \mathrm{ZnSO}_{4} \cdot 7 \mathrm{H}_{2} \mathrm{O}$ foliar application at the rate of 1,000 liters of solution ha ${ }^{-1}\left(+2.5 \mathrm{~kg} \mathrm{ha}^{-1}\right.$ lime) which supplied $1.0 \mathrm{~kg} \mathrm{Zn} \mathrm{ha}^{-1}$.

\subsection{Rice Transplanting}

Two 25-day-old seedlings of rice were transplanted per hill at $20 \mathrm{~cm} \times 10 \mathrm{~cm}$ in the first fortnight of July at both the places of study. The 'Pusa Sugandh 5', a derivative of Pusa 3A Karnal Basmati, is a semi-dwarf (90-100 cm height), high yielding basmati rice variety released in the year 2004 by the Indian Agricultural Research Institute, New Delhi, for commercial cultivation was transplanted in Meerut district of Uttar Pradesh. However, in Aligarh district 'Pusa Basmati 1' was transplanted which is an aromatic (Basmati) variety released from Indian Agricultural Research Institute, New Delhi, India during 1989 for its commercial cultivation. It is a cross between 'Pusa 150' and 'Karnal Lokal'. It produces long slender grains with good aroma and excellent cooking qualities (Rani et al., 2009; V. P. Singh \& A. K. Singh, 2009; Siddiq et al., 2012). Irrigation channels measuring 1 $\mathrm{m}$ wide were placed between the replications to ensure easy and uninterrupted flow of irrigation water where an individual plot was independently irrigated from the irrigation channels. Rice crop was grown as per recommended package of practices and was harvested in the second fortnight of October at both the places.

\subsection{Recording of Growth, Yield Attributes and Yields of Rice}

Ten hills were randomly selected in each plot for measuring plant height and fertile tillers hill ${ }^{-1} 10$ days before harvest and the average values were computed. Similarly, 10 panicles were randomly selected from each plot for recording the data on yield attributes (fertile tillers hill ${ }^{-1}$, panicle length, grains panicle ${ }^{-1}$ and 1,000-grain weight). At harvest, grain, straw and biological yields have been recorded for each plot and finally converted into tonnes $\mathrm{ha}^{-1}$. The rice grain yield was recorded at $14 \%$ moisture. The rough rice grains were hulled and rice kernel and rice husk yields were obtained which were used for chemical analysis of mineral nutrients such as $\mathrm{Zn}, \mathrm{Fe}, \mathrm{N}, \mathrm{P}$ and $\mathrm{K}$. 


\subsection{Chemical Analysis of Zn and Fe Concentration in Rice Kernel, Rice Husk and Rice Straw}

At harvest, samples of rice kernel, rice husk and rice starw were drawn from each plot of the experiment for the chemical analysis of $\mathrm{Zn}$ and $\mathrm{Fe}$ concentrations. $\mathrm{Zn}$ and $\mathrm{Fe}$ in rice kernel, husk and straw samples was analysed on a di-acid $\left(\mathrm{HClO}_{4}+\mathrm{HNO}_{3}\right.$ in 3:10 ratio) digest on an Atomic Absorption Spectrophotometer (Prasad et al., 2006). Thereafter, the uptake of the $\mathrm{Zn}$ and $\mathrm{Fe}$ was calculated by multiplying $\mathrm{Zn}$ and Fe concentrations with respective plot yield of rice kernel, rice husk and rice straw yields.

\subsection{Chemical Analysis of N, $P$ and $K$ in Rice Kernel, Rice Husk and Rice Straw}

At harvest, samples of rice kernel, rice husk and rice starw were drawn from each plot of the experiment for the chemical analysis of N, P and K as per the procedure described by Prasad et al. (2006). Finally recorded data in all the six replications were subjected to statistical analysis and final tabulation were done of the statistically analyzed data.

\subsection{Statistical Analysis}

All the data obtained from rice for this study were statistically analyzed using the $t$-test as per the procedure given by K. A. Gomez and A. A. Gomez (1984). LSD values at $P=0.05$ were used to determine the significance of differences between treatment means.

\section{Results}

\section{A. Aligarh Site}

\subsection{Yield Attributes}

$\mathrm{Zn}$ application significantly increased tillers $\mathrm{m}^{-2}$ and grains panicle ${ }^{-1}$ in rice, but not the panicle length and 1,000-grain weight (Table 1). Tillers $\mathrm{m}^{-2}$ and grains panicle ${ }^{-1}$ were the most with soil + foliar application of $\mathrm{Zn}$ sulphate $(\mathrm{ZnS})$, significantly more than soil application of $\mathrm{ZnS}$ or $\mathrm{Zn}$-coated urea $(\mathrm{ZnCU})$, which in turn was significantly superior to foliar application of $\mathrm{ZnS}$.

Table 1. Effect of various zinc treatments on yield attributes of aromatic rice [Aligarh, Uttar Pradesh site]

\begin{tabular}{|c|c|c|c|c|c|}
\hline Treatments & $\begin{array}{l}\text { Plant height } \\
(\mathrm{cm})\end{array}$ & Tillers $\mathrm{m}^{-2}$ & $\begin{array}{l}\text { Panicle } \\
\text { length }(\mathrm{cm})\end{array}$ & $\begin{array}{l}\text { Grains } \\
\text { panicle }^{-1} \text { (Nos.) }\end{array}$ & $\begin{array}{l}\text { 1,000-grain } \\
\text { weight }(\mathrm{g})\end{array}$ \\
\hline Check & 104 & 310 & 24 & 85 & 21.1 \\
\hline $5 \mathrm{~kg} \mathrm{Zn} \mathrm{ha}^{-1}$ (soil) & 107 & 326 & 26 & 91 & 22.2 \\
\hline $1 \mathrm{~kg} \mathrm{Zn} \mathrm{ha}^{-1}$ (foliar) & 105 & 318 & 25 & 88 & 22.0 \\
\hline $\begin{array}{l}5 \mathrm{~kg} \mathrm{Zn} \mathrm{ha}^{-1} \text { (soil) }+1 \mathrm{~kg} \mathrm{Zn} \mathrm{ha}{ }^{-1} \\
\text { (foliar) }\end{array}$ & 108 & 342 & 27 & 94 & 22.7 \\
\hline $\begin{array}{l}2.83 \mathrm{~kg} \mathrm{Zn} \mathrm{ha} \mathrm{ha}^{-1} \text { through } \\
\text { Zn-coated urea (soil) }\end{array}$ & 107 & 328 & 26 & 91 & 22.3 \\
\hline $\mathrm{SEm} \pm$ & 2.12 & 3.51 & 0.79 & 1.03 & 0.38 \\
\hline $\operatorname{LSD}(p=0.05)$ & NS & 9.95 & NS & 2.93 & NS \\
\hline
\end{tabular}

\subsection{Yields}

$\mathrm{Zn}$ application significantly increased grain and straw yield as well as harvest index of rice (Table 2). The highest values of grain, kernel, husk, straw and biological yield were obtained with soil + foliar application of $\mathrm{ZnS}$, followed by soil application of $\mathrm{ZnCU}$, which in turn was significantly superior to soil application of $\mathrm{ZnS}$ (Table 2). Foliar application of $\mathrm{ZnS}$ recorded the lowest values for all yields. Harvest index was also the highest for soil + foliar application of $\mathrm{ZnS}$ followed by $\mathrm{ZnCU}$, which in turn was followed by soil or foliar application of $\mathrm{ZnS}$. 
Table 2. Effect of various zinc treatments on yields of aromatic rice [Aligarh, Uttar Pradesh site]

\begin{tabular}{|c|c|c|c|c|c|c|}
\hline Treatments & $\begin{array}{l}\text { Rice grain } \\
\text { yield }\left(\mathrm{t} \mathrm{ha}^{-1}\right)\end{array}$ & $\begin{array}{l}\text { Rice kernel } \\
\text { yield }\left(\mathrm{t} \mathrm{ha}^{-1}\right)\end{array}$ & $\begin{array}{l}\text { Rice husk } \\
\text { yield }\left(\mathrm{t} \mathrm{ha}^{-1}\right)\end{array}$ & $\begin{array}{l}\text { Rice straw } \\
\text { yield }\left(\mathrm{t} \mathrm{ha}^{-1}\right)\end{array}$ & $\begin{array}{l}\text { Biological } \\
\text { yield }\left(\mathrm{t} \mathrm{ha}^{-1}\right)\end{array}$ & $\begin{array}{l}\text { Harvest } \\
\text { index }(\%)\end{array}$ \\
\hline Check & 3.58 & 2.40 & 1.18 & 6.80 & 10.38 & 34.5 \\
\hline $5 \mathrm{~kg} \mathrm{Zn} \mathrm{ha}^{-1}$ (soil) & 3.93 & 2.63 & 1.30 & 7.45 & 11.38 & 34.4 \\
\hline $1 \mathrm{~kg} \mathrm{Zn} \mathrm{ha}^{-1}$ (foliar) & 3.80 & 2.55 & 1.25 & 7.25 & 11.05 & 34.4 \\
\hline $\begin{array}{l}5 \mathrm{~kg} \mathrm{Zn} \mathrm{ha}^{-1} \text { (soil) }+1 \mathrm{~kg} \\
\mathrm{Zn} \mathrm{ha}^{-1} \text { (foliar) }\end{array}$ & 4.52 & 3.03 & 1.50 & 8.12 & 12.63 & 35.7 \\
\hline $\begin{array}{l}2.83 \mathrm{~kg} \mathrm{Zn} \mathrm{ha}^{-1} \text { through } \\
\text { Zn-coated urea (soil) }\end{array}$ & 4.10 & 2.75 & 1.35 & 7.63 & 11.73 & 35.1 \\
\hline $\mathrm{SEm} \pm$ & 0.03 & 0.02 & 0.01 & 0.03 & 0.04 & 0.21 \\
\hline $\operatorname{LSD}(p=0.05)$ & 0.08 & 0.06 & 0.03 & 0.09 & 0.11 & 0.60 \\
\hline
\end{tabular}

\subsection{Zn Concentration and Uptake}

$\mathrm{Zn}$ application increased $\mathrm{Zn}$ concentration in rice kernls, husk and straw and the highest values were obtained for soil + foliar application of $\mathrm{ZnS}$ (Table 3). In the case of kernels and straw soil + foliar application of $\mathrm{ZnS}$ recorded significantly higher $\mathrm{Zn}$ concentration than $\mathrm{ZnCU}$, which in turn was superior to soil or foliar application of $\mathrm{ZnS}$. In the case of husk $\mathrm{ZnCU}$ was superior to to foliar application of $\mathrm{ZnS}$, which in turn was superior to soil application of $\mathrm{ZnS}$. Foliar application of $\mathrm{ZnS}$ significantly increased $\mathrm{Zn}$ concentration in husk but not in kernels.

$\mathrm{Zn}$ application increased $\mathrm{Zn}$ uptake by rice. In husk and straw as well as in total $\mathrm{Zn}$ uptake by rice various treatments were in the following order: soil + foliar application of $\mathrm{ZnS}>\mathrm{ZnCU}>$ foliar application of $\mathrm{Zn}>$ soil application of $\mathrm{Zn}$; soil + foliar application recording the highest $\mathrm{Zn}$ uptake. However in the case of rice kernels, soil or foliar application of $\mathrm{Zn}$ recorded the same value for $\mathrm{Zn}$ uptake.

Table 3. Effect of various zinc treatments on zinc concentrations in rice kernel, rice husk, rice straw and their uptake in aromatic rice [Aligarh, Uttar Pradesh site]

\begin{tabular}{|c|c|c|c|c|c|c|c|}
\hline Treatments & 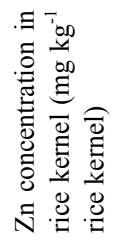 & 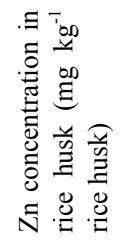 & 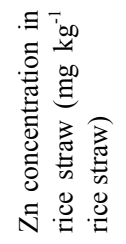 & 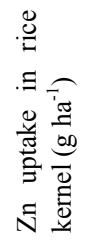 & 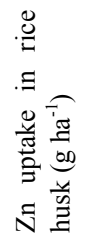 & 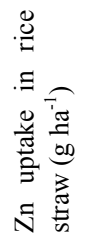 & 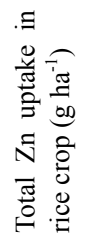 \\
\hline Check & 20.0 & 125.0 & 91.0 & 48.0 & 147.5 & 618.8 & 814.3 \\
\hline $5 \mathrm{~kg} \mathrm{Zn} \mathrm{ha}^{-1}$ (soil) & 21.3 & 130.0 & 100.0 & 56.0 & 169.0 & 745.0 & 970.0 \\
\hline $1 \mathrm{~kg} \mathrm{Zn} \mathrm{ha}{ }^{-1}$ (foliar) & 22.0 & 147.0 & 102.0 & 56.1 & 183.8 & 739.5 & 979.4 \\
\hline $5 \mathrm{~kg} \mathrm{Zn} \mathrm{ha}^{-1}$ (soil) $+1 \mathrm{~kg} \mathrm{Zn} \mathrm{ha}^{-1}$ (foliar) & 25.0 & 175.0 & 107.0 & 75.7 & 262.5 & 868.8 & 1207.0 \\
\hline $2.83 \mathrm{~kg} \mathrm{Zn} \mathrm{ha}^{-1}$ through $\mathrm{Zn}$-coated urea (soil) & 23.8 & 170.0 & 105.0 & 65.5 & 229.5 & 801.2 & 1096.2 \\
\hline $\mathrm{SEm} \pm$ & 0.30 & 1.46 & 0.98 & 1.07 & 2.41 & 7.95 & 9.27 \\
\hline $\operatorname{LSD}(p=0.05)$ & 0.86 & 4.13 & 2.78 & 3.02 & 6.82 & 22.55 & 26.26 \\
\hline
\end{tabular}

\subsection{Iron Concentration and Uptake}

Soil application of $\mathrm{ZnS}$ or $\mathrm{ZnCU}$ significantly increased Fe concentration in rice kernels, husk and straw. In the case of kernels and husk, soil application of $\mathrm{ZnS}, \mathrm{ZnCU}$ or soil + foliar application of $\mathrm{ZnS}$ were at par (Table 4). However, soil + foliar application of $\mathrm{ZnS}$ or $\mathrm{ZnCU}$ recorded significantly higher concentration in rice straw than soil application of $\mathrm{ZnS}$. Foliar application of $\mathrm{ZnS}$ had no effect on Fe concentration by rice.

$\mathrm{Zn}$ application increased $\mathrm{Fe}$ uptake by rice. As regards grain and straw and total $\mathrm{Fe}$ uptake by rice, different 
treatments were in the following order: soil + foliar application of $\mathrm{ZnS}>\mathrm{ZnCU}>$ soil aplication of $\mathrm{ZnS}>$ foliar application of $\mathrm{ZnS}$. In the case of husk soil application of $\mathrm{ZnS}$ and $\mathrm{ZnCU}$ were at par. In general, as a contrast to $\mathrm{Zn}$ uptake, soil application of $\mathrm{Zn}$ recorded the higher Fe uptake than foliar application of $\mathrm{ZnS}$.

Table 4. Effect of various zinc treatments on Fe concentrations in rice kernel, rice husk, rice straw and their uptake in aromatic rice [Aligarh, Uttar Pradesh site]

\begin{tabular}{|c|c|c|c|c|c|c|c|}
\hline Treatments & 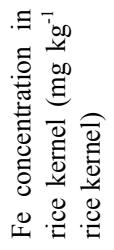 & 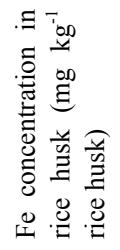 & 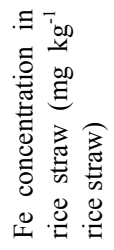 & 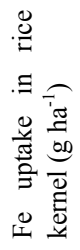 & 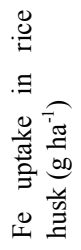 & 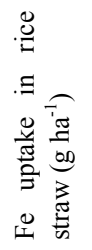 & 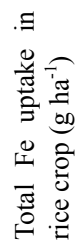 \\
\hline Check & 8.2 & 12.3 & 42.0 & 19.7 & 14.5 & 285.6 & 319.8 \\
\hline $5 \mathrm{~kg} \mathrm{Zn} \mathrm{ha}^{-1}$ (soil) & 9.0 & 13.4 & 48.0 & 23.7 & 17.4 & 357.6 & 398.7 \\
\hline $1 \mathrm{~kg} \mathrm{Zn} \mathrm{ha}{ }^{-1}$ (foliar) & 8.4 & 12.8 & 45.0 & 21.4 & 16.0 & 326.3 & 363.7 \\
\hline $5 \mathrm{~kg} \mathrm{Zn} \mathrm{ha}^{-1}$ (soil) $+1 \mathrm{~kg} \mathrm{Zn} \mathrm{ha}^{-1}$ (foliar) & 9.3 & 14.1 & 55.0 & 28.2 & 21.2 & 446.6 & 496.0 \\
\hline $2.83 \mathrm{~kg} \mathrm{Zn} \mathrm{ha}^{-1}$ through $\mathrm{Zn}$-coated urea (soil) & 9.1 & 13.8 & 56.0 & 25.0 & 18.6 & 427.3 & 470.9 \\
\hline $\mathrm{SEm} \pm$ & 0.15 & 0.39 & 0.58 & 0.79 & 0.53 & 4.55 & 4.59 \\
\hline $\operatorname{LSD}(p=0.05)$ & 0.44 & 1.10 & 1.66 & 2.24 & 1.51 & 12.88 & 13.01 \\
\hline
\end{tabular}

\subsection{Nitrogen Concentration and Uptake}

$\mathrm{Zn}$ application significantly increased $\mathrm{N}$ concentration and crude protein content in rice kernel and $\mathrm{N}$ concentration in straw. In general, soil + foliar application of $\mathrm{ZnS}$ or $\mathrm{ZnCU}$ recorded significantly higher $\mathrm{N}$ concentration in rice kernel and straw than foliar application of $\mathrm{ZnS}$ (Table 5). The $\mathrm{N}$ concentration in rice kernel was about 2.5 times of that in straw.

As regards $\mathrm{N}$ uptake by rice kernel, straw as well as total $\mathrm{N}$ uptake by rice crop, different treatments were in the following order: soil + foliar application of $\mathrm{ZnS}>$ soil application of $\mathrm{ZnCU}>$ soil application of $\mathrm{ZnS}>$ foliar application of $\mathrm{ZnS}$; soil + foliar application recording the highest $\mathrm{N}$ uptake.

Table 5. Effect of various zinc treatments on $\mathrm{N}$ concentrations in rice kernel, rice husk, rice straw and their uptake in aromatic rice and crude protein content in brown rice [Aligarh, Uttar Pradesh site]

\begin{tabular}{|c|c|c|c|c|c|c|}
\hline Treatments & 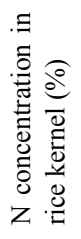 & 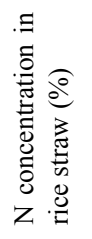 & 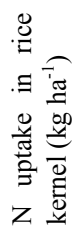 & 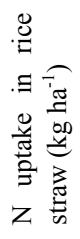 & 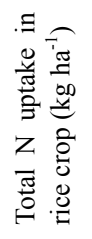 & 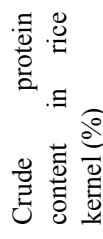 \\
\hline Check & 1.50 & 0.62 & 36.0 & 42.2 & 78.2 & 8.92 \\
\hline $5 \mathrm{~kg} \mathrm{Zn} \mathrm{ha}^{-1}$ (soil) & 1.60 & 0.66 & 42.1 & 49.2 & 91.3 & 9.52 \\
\hline $1 \mathrm{~kg} \mathrm{Zn} \mathrm{ha}^{-1}$ (foliar) & 1.53 & 0.64 & 39.0 & 46.4 & 85.4 & 9.10 \\
\hline $5 \mathrm{~kg} \mathrm{Zn} \mathrm{ha}^{-1}$ (soil) $+1 \mathrm{~kg} \mathrm{Zn} \mathrm{ha}^{-1}$ (foliar) & 1.62 & 0.67 & 49.1 & 54.4 & 103.5 & 9.64 \\
\hline $2.83 \mathrm{~kg} \mathrm{Zn} \mathrm{ha}^{-1}$ through $\mathrm{Zn}$-coated urea (soil) & 1.61 & 0.67 & 44.3 & 51.1 & 95.4 & 9.58 \\
\hline $\mathrm{SEm} \pm$ & 0.007 & 0.005 & 0.54 & 0.41 & 0.61 & 0.05 \\
\hline $\operatorname{LSD}(p=0.05)$ & 0.020 & 0.015 & 1.54 & 1.16 & 1.72 & 0.14 \\
\hline
\end{tabular}

\subsection{Phosphorus Concentration and Uptake}

A significant increase in $\mathrm{P}$ concentration in rice due to $\mathrm{Zn}$ application was recorded only in kernels, where soil 
application of $\mathrm{ZnS}$ recorded significantly higher $\mathrm{P}$ concentration than foliar application of $\mathrm{ZnS}$ or soil application of ZnS. Least P concentration was recorded with soil + foliar application of ZnS (Table 6).

Uptake of P by kernel was much more than that by husk or straw. In kernels and total P uptake by rice was the highest with soil application of $\mathrm{ZnS}$ followed by soil + foliar application of $\mathrm{ZnS}$ or $\mathrm{ZnCU}$, which were at par. Least $\mathrm{P}$ uptake by kernels and total $\mathrm{P}$ uptake by the rice crop was recorded with foliar application of $\mathrm{ZnS}$.

Table 6. Effect of various zinc treatments on $\mathrm{P}$ concentrations in rice kernel, rice husk, rice straw and their uptake in aromatic rice [Aligarh, Uttar Pradesh site]

\begin{tabular}{|c|c|c|c|c|c|c|c|}
\hline Treatments & 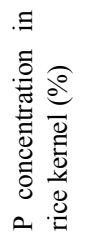 & 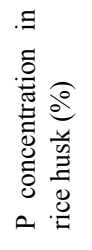 & 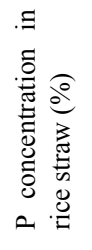 & 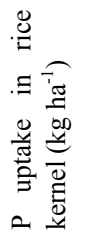 & 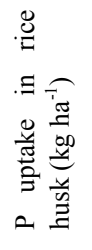 & 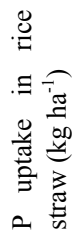 & 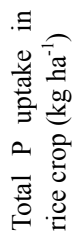 \\
\hline Check & 0.64 & 0.03 & 0.07 & 15.36 & 0.35 & 4.76 & 20.47 \\
\hline $5 \mathrm{~kg} \mathrm{Zn} \mathrm{ha}^{-1}$ (soil) & 0.73 & 0.04 & 0.08 & 19.20 & 0.52 & 5.96 & 27.68 \\
\hline $1 \mathrm{~kg} \mathrm{Zn} \mathrm{ha}{ }^{-1}$ (foliar) & 0.64 & 0.03 & 0.08 & 16.32 & 0.38 & 5.80 & 22.56 \\
\hline $5 \mathrm{~kg} \mathrm{Zn} \mathrm{ha}^{-1}$ (soil) $+1 \mathrm{~kg} \mathrm{Zn} \mathrm{ha}^{-1}$ (foliar) & 0.61 & 0.03 & 0.08 & 18.48 & 0.45 & 6.50 & 25.43 \\
\hline $2.83 \mathrm{~kg} \mathrm{Zn} \mathrm{ha}^{-1}$ through $\mathrm{Zn}$-coated urea (soil) & 0.65 & 0.04 & 0.08 & 17.87 & 0.54 & 6.10 & 24.51 \\
\hline $\mathrm{SEm} \pm$ & 0.007 & 0.002 & 0.005 & 0.66 & 0.021 & 0.26 & 0.44 \\
\hline $\operatorname{LSD}(p=0.05)$ & 0.020 & 0.004 & NS & 0.75 & 0.060 & 0.75 & 1.24 \\
\hline
\end{tabular}

\subsection{Potassium Concentration and Uptake}

$\mathrm{Zn}$ application significantly increased $\mathrm{K}$ concentration in kernels only and soil application of $\mathrm{ZnS}$ and soil + foliar application of $\mathrm{ZnS}$ were at par significantly superior to soil application of $\mathrm{ZnCU}$ or foliar application of $\mathrm{Zn}$ (Table 7).

As regards $\mathrm{K}$ uptake in kernels, soil + foliar application of $\mathrm{ZnS}$ recorded the highest $\mathrm{K}$ uptake followed by the soil application of $\mathrm{ZnCU}$ and soil or foliar application of $\mathrm{ZnS}$. In husk the treatments were in the following order: soil + foliar application of $\mathrm{ZnS}>$ soil application of $\mathrm{ZnCU}$ or $\mathrm{ZnS}>$ foliar application of $\mathrm{ZnS}$. Straw contributed most to $\mathrm{K}$ uptake by rice and different treatments were in the following order: soil + foliar application of $\mathrm{ZnS}>$ soil application of $\mathrm{ZnCU}>$ soil application of $\mathrm{ZnS}>$ foliar application of $\mathrm{ZnS}$.

Table 7. Effect of various zinc treatments on $\mathrm{K}$ concentrations in rice kernel, rice husk, rice straw and their uptake in aromatic rice [Aligarh, Uttar Pradesh site]

\begin{tabular}{|c|c|c|c|c|c|c|c|}
\hline Treatments & 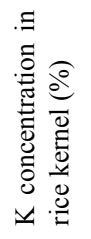 & 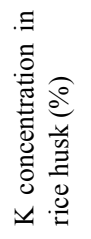 & 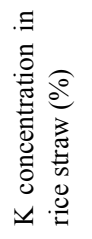 & 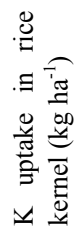 & 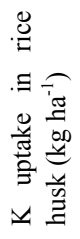 & 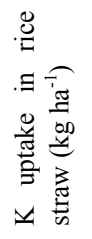 & 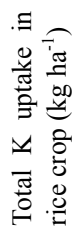 \\
\hline Check & 0.18 & 0.47 & 3.40 & 4.32 & 5.55 & 231.2 & 241.1 \\
\hline $5 \mathrm{~kg} \mathrm{Zn} \mathrm{ha}^{-1}$ (soil) & 0.20 & 0.49 & 3.67 & 4.26 & 6.37 & 273.4 & 285.0 \\
\hline $1 \mathrm{~kg} \mathrm{Zn} \mathrm{ha}^{-1}$ (foliar) & 0.19 & 0.47 & 3.53 & 4.84 & 5.88 & 255.9 & 266.6 \\
\hline $5 \mathrm{~kg} \mathrm{Zn} \mathrm{ha}^{-1}$ (soil) $+1 \mathrm{~kg} \mathrm{Zn} \mathrm{ha}^{-1}$ (foliar) & 0.21 & 0.50 & 3.70 & 6.36 & 7.50 & 300.4 & 314.3 \\
\hline $2.83 \mathrm{~kg} \mathrm{Zn} \mathrm{ha}^{-1}$ through $\mathrm{Zn}$-coated urea (soil) & 0.19 & 0.49 & 3.68 & 5.22 & 6.62 & 280.8 & 292.6 \\
\hline $\mathrm{SEm} \pm$ & 0.004 & 0.007 & 0.013 & 0.12 & 0.11 & 1.52 & 2.11 \\
\hline $\operatorname{LSD}(p=0.05)$ & 0.012 & 0.021 & 0.037 & 0.34 & 0.31 & 4.31 & 5.99 \\
\hline
\end{tabular}




\subsection{Zn, N, P and $K$ Concentration in Fag Leaf}

$\mathrm{Zn}$ application significantly increased $\mathrm{Zn}, \mathrm{N}$ and $\mathrm{K}$ concentration but not the $\mathrm{P}$ concentration in rice flag leaf (Table 8). Soil + foliar application of $\mathrm{ZnS}$ and soil applicastion of $\mathrm{ZnCU}$ were at par and significantly superior to soil or foliar application of $\mathrm{ZnS}$. As regards $\mathrm{N}$ concentration in flag leaf, different treatments were in the following order: soil application of $\mathrm{ZnCU}>$ soil + foliar applcation of $\mathrm{ZnS}>$ soil application of $\mathrm{ZnS}>$ foliar application of $\mathrm{ZnS}$.

Table 8. Effect of various zinc treatments on $\mathrm{Zn}, \mathrm{Fe}, \mathrm{N}, \mathrm{P}$ and $\mathrm{K}$ concentrations in aromatic rice flag leaf [Aligarh, Uttar Pradesh site]

\begin{tabular}{lllll}
\hline Treatments & $\begin{array}{l}\text { Zn concentration in } \\
\text { rice flag leaf }(\mathrm{mg} \\
\mathrm{kg}^{-1} \text { rice leaf DM) }\end{array}$ & $\begin{array}{l}\mathrm{N} \text { concentration } \\
\text { in rice leaf }(\%)\end{array}$ & $\begin{array}{l}\text { P concentration in } \\
\text { rice flag leaf (\%) }\end{array}$ & $\begin{array}{l}\mathrm{K} \text { content in rice } \\
\text { flag leaf (\%) }\end{array}$ \\
\hline Check & 95.0 & 1.29 & 0.35 & 4.04 \\
$5 \mathrm{~kg} \mathrm{Zn} \mathrm{ha}^{-1}$ (soil) & 105.0 & 1.39 & 0.36 & 4.31 \\
$1 \mathrm{~kg} \mathrm{Zn} \mathrm{ha}^{-1}$ (foliar) & 107.0 & 1.32 & 0.40 & 4.15 \\
$5 \mathrm{~kg} \mathrm{Zn} \mathrm{ha}^{-1}$ (soil) $+1 \mathrm{~kg} \mathrm{Zn} \mathrm{ha}^{-1}$ (foliar) & 112.0 & 1.41 & 0.41 & 4.47 \\
$2.83 \mathrm{~kg} \mathrm{Zn} \mathrm{ha}^{-1}$ through Zn-coated urea (soil) & 111.0 & 1.46 & 0.42 & 4.58 \\
$\mathrm{SEm} \pm$ & 1.01 & 0.005 & 0.025 & 0.06 \\
$\mathrm{LSD}(p=0.05)$ & 2.86 & 0.014 & 0.072 & 0.16 \\
\hline
\end{tabular}

\section{B. Meerut Site}

\subsection{Yield Attributes}

$\mathrm{Zn}$ application significantly increased tillers $\mathrm{m}^{-2}$ and grains panicle ${ }^{-1}$ but not the panicle length and 1,000-grain weight (Table 9). Soil application of $\mathrm{ZnS}$ or $\mathrm{ZnCU}$ or soil + foliar application of $\mathrm{ZnS}$ resulted in significantly more effective tillers than foliar application of $\mathrm{ZnS}$. The highest number of grains panicle ${ }^{-1}$ were produced by soil application of $\mathrm{ZnS}$ or $\mathrm{ZnCU}$.

Table 9. Effect of various zinc treatments on yield attributes of aromatic rice [Meerut, Uttar Pradesh site]

\begin{tabular}{llllll}
\hline Treatments & $\begin{array}{l}\text { Plant } \\
\text { height }(\mathrm{cm})\end{array}$ & $\begin{array}{l}\text { Effective } \\
\text { tillers hill }\end{array}$ & $\begin{array}{l}\text { Panicle } \\
\text { length }(\mathrm{cm})\end{array}$ & $\begin{array}{l}\text { Grains panicle } \\
\text { (Nos.) }\end{array}$ & $\begin{array}{l}1,000 \text {-grain } \\
\text { weight }(\mathrm{g})\end{array}$ \\
\hline Check & 105 & 7.1 & 27.0 & 124 & 24.0 \\
$5 \mathrm{~kg} \mathrm{Zn} \mathrm{ha}^{-1}$ (soil) & 108 & 7.8 & 27.7 & 131 & 24.5 \\
$1 \mathrm{~kg} \mathrm{Zn} \mathrm{ha}^{-1}$ (foliar) & 107 & 7.3 & 27.4 & 128 & 24.3 \\
$5 \mathrm{~kg} \mathrm{Zn} \mathrm{ha}^{-1}$ (soil) $+1 \mathrm{~kg} \mathrm{Zn} \mathrm{ha}^{-1}$ (foliar) & 109 & 8.0 & 28.0 & 125 & 24.7 \\
$\begin{array}{l}2.83 \mathrm{~kg} \mathrm{Zn} \mathrm{ha}^{-1} \text { through Zn-coated urea } \\
(\operatorname{soil})\end{array}$ & 109 & 7.8 & 27.8 & 131 & 24.5 \\
$\mathrm{SEm} \pm$ & 2.25 & 0.10 & 0.63 & 1.20 & 0.40 \\
$\mathrm{LSD}(p=0.05)$ & $\mathrm{NS}$ & 0.27 & $\mathrm{NS}$ & 3.40 & $\mathrm{NS}$ \\
\hline
\end{tabular}

\subsection{Yields}

$\mathrm{Zn}$ application significantly increased grain and straw yield as well as harvest index in rice (Table 10). Soil + foliar application of $\mathrm{ZnS}$ recorded significantly more grain, kernel, husk and total biological yield than other treatments. As regards straw yield, soil + foliar appplication of $\mathrm{ZnS}$ was at par with soil application of $\mathrm{ZnCU}$ and both these treatments were significantly superior to soil or foliar application of $\mathrm{ZnS}$. Harvest index was not significantly affected by $\mathrm{Zn}$ application. 
Table 10. Effect of various zinc treatments on yields of aromatic rice [Meerut, Uttar Pradesh site]

\begin{tabular}{|c|c|c|c|c|c|c|}
\hline Treatments & $\begin{array}{l}\text { Rice grain } \\
\text { yield }\left(\mathrm{t} \mathrm{ha}^{-1}\right)\end{array}$ & $\begin{array}{l}\text { Rice kernel } \\
\text { yield }\left(\mathrm{t} \mathrm{ha}^{-1}\right)\end{array}$ & $\begin{array}{l}\text { Rice husk } \\
\text { yield }\left(\mathrm{t} \mathrm{ha}^{-1}\right)\end{array}$ & $\begin{array}{l}\text { Rice straw } \\
\text { yield }\left(\mathrm{t} \mathrm{ha}^{-1}\right)\end{array}$ & $\begin{array}{l}\text { Biological } \\
\text { yield }\left(\mathrm{t} \mathrm{ha}^{-1}\right)\end{array}$ & $\begin{array}{l}\text { Harvest } \\
\text { index (\%) }\end{array}$ \\
\hline Check & 5.40 & 3.62 & 1.78 & 8.50 & 13.90 & 38.8 \\
\hline $5 \mathrm{~kg} \mathrm{Zn} \mathrm{ha}^{-1}$ (soil) & 5.70 & 3.82 & 1.88 & 8.90 & 14.60 & 39.0 \\
\hline $1 \mathrm{~kg} \mathrm{Zn} \mathrm{ha}^{-1}$ (foliar) & 5.60 & 3.75 & 1.85 & 8.70 & 14.30 & 39.2 \\
\hline $\begin{array}{l}5 \mathrm{~kg} \mathrm{Zn} \mathrm{ha}{ }^{-1} \text { (soil) }+1 \mathrm{~kg} \mathrm{Zn} \mathrm{ha}{ }^{-1} \\
\text { (foliar) }\end{array}$ & 6.00 & 4.02 & 1.98 & 9.20 & 15.20 & 39.5 \\
\hline $\begin{array}{l}2.83 \mathrm{~kg} \mathrm{Zn} \mathrm{ha}{ }^{-1} \text { through } \mathrm{Zn} \text {-coated } \\
\text { urea (soil) }\end{array}$ & 5.70 & 3.82 & 1.88 & 9.00 & 14.70 & 38.8 \\
\hline $\mathrm{SEm} \pm$ & 0.09 & 0.07 & 0.03 & 0.09 & 0.14 & 0.44 \\
\hline $\operatorname{LSD}(p=0.05)$ & 0.27 & 0.20 & 0.09 & 0.26 & 0.40 & NS \\
\hline
\end{tabular}

\subsection{Zinc Concntration and Uptake}

$\mathrm{Zn}$ application increased $\mathrm{Zn}$ concentation in rice kernel, husk and straw of rice (Table 11). Zn concentration in rice kernels was the highest with soil application of $\mathrm{ZnCU}$, signicantly more than that obtained with soil + foliar application of $\mathrm{ZnS}$, which in turn was superior to foliar application of $\mathrm{ZnS}$. However, foliar application of $\mathrm{ZnS}$ recorded significantly more $\mathrm{Zn}$ concentration in rice kernels than soil aplication of $\mathrm{ZnS}$. $\mathrm{Zn}$ concentration in rice husk was the highest with soil + foliar application of $\mathrm{ZnS}$, significantly superior to foliar application of $\mathrm{ZnS}$, which in turn was superior to $\mathrm{ZnCU}$. Lowest $\mathrm{Zn}$ concentration was obtained with soil application of $\mathrm{ZnS}$. As regards $\mathrm{Zn}$ concentration in straw, soil + foliar application of $\mathrm{ZnS}$ and soil application of $\mathrm{ZnCU}$ were at par and significantly superior to foliar application of $\mathrm{ZnS}$, which in turn was superior to soil application of $\mathrm{ZnS}$.

$\mathrm{Zn}$ uptake significantly increased $\mathrm{Zn}$ uptake by rice kernels, husk and straw in rice and this resulted in a significant increase in total $\mathrm{Zn}$ uptake by rice. As regards rice kernels soil + foliar application of $\mathrm{ZnS}$ and soil application of $\mathrm{ZnCU}$ were at par and significantly superior to soil or foliar application of $\mathrm{ZnS}$. In the case of rice husk, foliar aplication of $\mathrm{ZnS}$ was next only to soil + foliar application of $\mathrm{ZnS}$ and was followed by soil application of $\mathrm{ZnCU}$. Soil application of $\mathrm{ZnS}$ recorded the least $\mathrm{Zn}$ uptake by rice.

Table 11. Effect of various zinc treatments on $\mathrm{Zn}$ concentrations in rice kernel, rice husk, rice straw and their uptake in aromatic rice [Meerut, Uttar Pradesh site]

\begin{tabular}{|c|c|c|c|c|c|c|c|}
\hline Treatments & 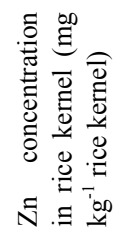 & 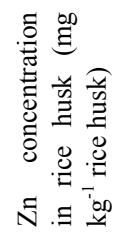 & 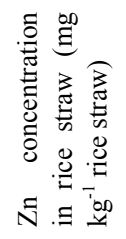 & 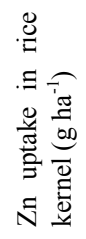 & 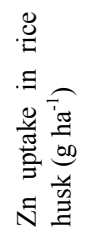 & 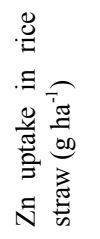 & 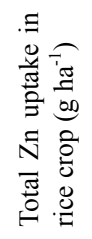 \\
\hline Check & 18.0 & 17.7 & 110.3 & 65.2 & 31.5 & 937.6 & 1034.3 \\
\hline $5 \mathrm{~kg} \mathrm{Zn} \mathrm{ha}^{-1}$ (soil) & 18.7 & 23.8 & 117.0 & 71.4 & 44.7 & 1041.3 & 1157.4 \\
\hline $1 \mathrm{~kg} \mathrm{Zn} \mathrm{ha}^{-1}$ (foliar) & 20.2 & 34.7 & 124.2 & 75.8 & 64.2 & 1080.5 & 1220.5 \\
\hline $5 \mathrm{~kg} \mathrm{Zn} \mathrm{ha}^{-1}$ (soil) $+1 \mathrm{~kg} \mathrm{Zn} \mathrm{ha}^{-1}$ (foliar) & 21.2 & 37.7 & 126.0 & 85.2 & 74.6 & 1159.2 & 1319.0 \\
\hline $2.83 \mathrm{~kg} \mathrm{Zn} \mathrm{ha}^{-1}$ through $\mathrm{Zn}$-coated urea (soil) & 22.2 & 25.7 & 124.8 & 84.8 & 48.3 & 1123.2 & 1256.3 \\
\hline $\mathrm{SEm} \pm$ & 0.28 & 0.42 & 0.49 & 2.57 & 1.29 & 15.3 & 15.76 \\
\hline $\operatorname{LSD}(p=0.05)$ & 0.79 & 1.20 & 1.40 & 7.30 & 3.65 & 43.3 & 44.65 \\
\hline
\end{tabular}

\subsection{Iron Concentration and Uptake}

Fe concentration in rice kernels, husk and straw was increased by $\mathrm{Zn}$ application and for all the components soil + foliar application of $\mathrm{ZnS}$ or $\mathrm{ZnCU}$ were at par and significantly superior to foliar application of $\mathrm{ZnS}$ (Table 12). Foliar application of $\mathrm{ZnS}$ had no significant effect on Fe concentration in rice kernels, husk and straw. 
All treatments except foliar application of Zn significantly increased Fe uptake by rice kernels, husk and straw and total Fe uptake by rice crop.

Table 12. Effect of various zinc treatments on Fe concentrations in rice kernel, rice husk, rice straw and their uptake in aromatic rice [Meerut, Uttar Pradesh site]

\begin{tabular}{|c|c|c|c|c|c|c|c|}
\hline Treatments & 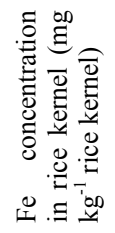 & 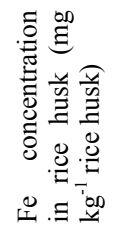 & 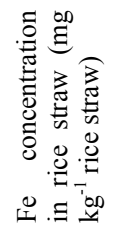 & 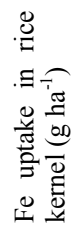 & 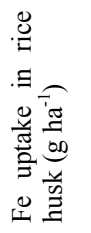 & 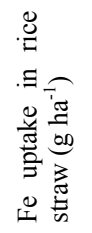 & 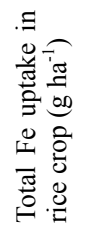 \\
\hline Check & 21.2 & 56.0 & 98.2 & 76.7 & 99.7 & 834.7 & 1011.1 \\
\hline $5 \mathrm{~kg} \mathrm{Zn} \mathrm{ha}^{-1}$ (soil) & 22.4 & 58.0 & 103.6 & 85.6 & 109.0 & 922.0 & 1116.6 \\
\hline $1 \mathrm{~kg} \mathrm{Zn} \mathrm{ha}^{-1}$ (foliar) & 21.6 & 55.0 & 100.3 & 81.0 & 101.8 & 872.6 & 1055.4 \\
\hline $5 \mathrm{~kg} \mathrm{Zn} \mathrm{ha}^{-1}$ (soil) $+1 \mathrm{~kg} \mathrm{Zn} \mathrm{ha}^{-1}$ (foliar) & 22.8 & 58.0 & 105.2 & 91.7 & 114.8 & 967.8 & 1174.3 \\
\hline $2.83 \mathrm{~kg} \mathrm{Zn} \mathrm{ha}^{-1}$ through $\mathrm{Zn}$-coated urea (soil) & 22.7 & 58.0 & 104.3 & 86.7 & 109.0 & 938.7 & 1134.4 \\
\hline $\mathrm{SEm} \pm$ & 0.37 & 0.50 & 1.59 & 2.26 & 2.23 & 24.26 & 29.07 \\
\hline $\operatorname{LSD}(p=0.05)$ & 1.06 & 1.42 & 4.51 & 6.40 & 6.31 & 68.34 & 82.37 \\
\hline
\end{tabular}

\subsection{Nitrogen Concentration and Uptake}

Nitrogen concentration and crude protein content in rice kernels was significntly increased due to $\mathrm{Zn}$ fertilization and soil + foliar application of $\mathrm{ZnS}$ and soil application of $\mathrm{ZnCU}$ were at par and significantly superior to soil application of $\mathrm{ZnS}$, which in turn was significantly superior to foliar application of ZnS (Table 13).

Nitrogen uptake by rice kernels and straw and total $\mathrm{N}$ uptake by the rice crop was most with soil + foliar application $\mathrm{ZnS}$ or $\mathrm{ZnCU}$, which were at par. Foliar application of $\mathrm{ZnS}$ recorded the lowest $\mathrm{N}$ uptake.

Table 13. Effect of various zinc treatments on $\mathrm{N}$ concentrations in rice kernel, rice straw and their uptake in aromatic rice and also crude protein content [Meerut, Uttar Pradesh site]

\begin{tabular}{|c|c|c|c|c|c|c|}
\hline Treatments & 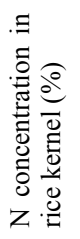 & 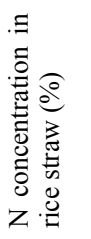 & 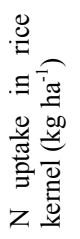 & 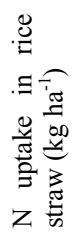 & 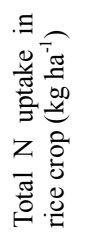 & 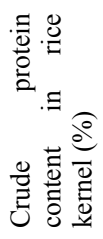 \\
\hline Check & 1.29 & 0.79 & 46.7 & 67.1 & 113.8 & 7.7 \\
\hline $5 \mathrm{~kg} \mathrm{Zn} \mathrm{ha}^{-1}$ (soil) & 1.43 & 0.89 & 54.6 & 79.2 & 133.8 & 8.5 \\
\hline $1 \mathrm{~kg} \mathrm{Zn} \mathrm{ha}^{-1}$ (foliar) & 1.34 & 0.85 & 50.2 & 74.0 & 124.2 & 8.0 \\
\hline $5 \mathrm{~kg} \mathrm{Zn} \mathrm{ha}^{-1}$ (soil) $+1 \mathrm{~kg} \mathrm{Zn} \mathrm{ha}^{-1}$ (foliar) & 1.50 & 0.92 & 60.3 & 84.6 & 144.9 & 8.9 \\
\hline $2.83 \mathrm{~kg} \mathrm{Zn} \mathrm{ha}^{-1}$ through $\mathrm{Zn}$-coated urea (soil) & 1.47 & 0.85 & 56.2 & 76.5 & 132.7 & 8.7 \\
\hline $\mathrm{SEm} \pm$ & 0.01 & 0.005 & 1.55 & 1.23 & 2.39 & 0.08 \\
\hline $\operatorname{LSD}(p=0.05)$ & 0.03 & 0.014 & 4.41 & 3.48 & 6.77 & 0.23 \\
\hline
\end{tabular}

\subsection{Phosphorus Concentration and Uptake}

In rice kernels soil application of $\mathrm{ZnCU}$ recorded the highest $\mathrm{P}$ concentration and was followed by soil + foliar application of $\mathrm{ZnS}$, which in turn was significantly superior to soil application of $\mathrm{ZnS}$ (Table 14). In the case of husk, however, soil + foliar application of $\mathrm{ZnS}$ was superior to soil application of $\mathrm{ZnS}$ or $\mathrm{ZnCU}$, which were at par. In straw, soil application of $\mathrm{ZnCU}$ recorded the highest $\mathrm{P}$ concentration followed by soil application of $\mathrm{ZnS}$, 
which in turn was significantly superior to soil + foliar application of ZnS.

Phosphorus uptake by rice kernels was increased by soil application of $\mathrm{ZnS}$ or $\mathrm{ZnCU}$ or soil + foliar application of $\mathrm{ZnS}$, which were at par. Foliar application of $\mathrm{ZnS}$ did not increase $\mathrm{P}$ uptake by rice crop. Zn application did not increase P uptake by husk. However in rice straw, different treatrments were in the following order: soil application of $\mathrm{ZnCU}>$ soil application of $\mathrm{ZnS}>$ soil + foliar application of $\mathrm{Zn}>$ foliar application of $\mathrm{ZnS}$. Soil application of $\mathrm{ZnCU}$ recorded the highest $\mathrm{P}$ uptake, significantly higher than soil + foliar application of $\mathrm{ZnS}$ or soil application of $\mathrm{ZnS}$ Foliar application of $\mathrm{ZnS}$ did not increase $\mathrm{P}$ uptake by rice.

Table 14. Effect of various zinc treatments on $\mathrm{P}$ concentrations in rice kernel, rice husk, rice straw and their uptake in aromatic rice [Meerut, Uttar Pradesh site]

\begin{tabular}{|c|c|c|c|c|c|c|c|}
\hline Treatments & 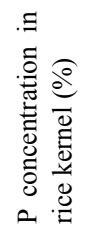 & 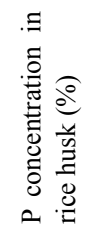 & 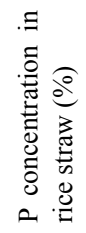 & 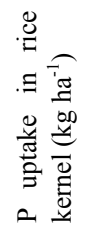 & 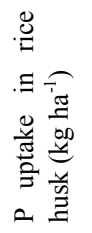 & 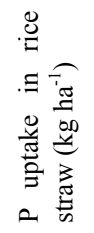 & 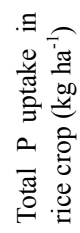 \\
\hline Check & 0.58 & 0.063 & 0.14 & 21.00 & 1.12 & 11.90 & 34.02 \\
\hline $5 \mathrm{~kg} \mathrm{Zn} \mathrm{ha}^{-1}$ (soil) & 0.66 & 0.065 & 0.19 & 25.21 & 1.22 & 16.91 & 43.34 \\
\hline $1 \mathrm{~kg} \mathrm{Zn} \mathrm{ha}^{-1}$ (foliar) & 0.55 & 0.063 & 0.15 & 20.62 & 1.16 & 13.05 & 34.83 \\
\hline $5 \mathrm{~kg} \mathrm{Zn} \mathrm{ha}^{-1}$ (soil) $+1 \mathrm{~kg} \mathrm{Zn} \mathrm{ha}^{-1}$ (foliar) & 0.63 & 0.067 & 0.16 & 25.33 & 1.33 & 14.72 & 41.38 \\
\hline $2.83 \mathrm{~kg} \mathrm{Zn} \mathrm{ha}^{-1}$ through $\mathrm{Zn}$-coated urea (soil) & 0.66 & 0.065 & 0.21 & 25.21 & 1.22 & 18.9 & 45.33 \\
\hline $\mathrm{SEm} \pm$ & 0.006 & 0.0004 & 0.004 & 0.49 & 0.086 & 0.48 & 1.035 \\
\hline $\operatorname{LSD}(p=0.05)$ & 0.016 & 0.0011 & 0.011 & 1.38 & 0.283 & 1.37 & 2.931 \\
\hline
\end{tabular}

\subsection{Potassium Concentration and Uptake}

A significant increase in $\mathrm{K}$ concentration in rice kernels was obtained only with soil + foliar application of $\mathrm{ZnS}$ or soil application of $\mathrm{ZnCU}$ (Table 15). There was no significant increase in $\mathrm{K}$ uptake due to $\mathrm{Zn}$ application. In the case of rice straw, soil application of $\mathrm{ZnS}$ or $\mathrm{ZnCU}$ or soil + foliar application of $\mathrm{ZnS}$ were at par and significantly superior to foliar application of $\mathrm{ZnS}$.

Foliar application of ZnS did not significantly increase $\mathrm{K}$ uptake in rice kernels or husk, but did so in straw and therefore in total $\mathrm{K}$ uptake by rice crop. Soil application of $\mathrm{ZnS}$ or $\mathrm{ZnCU}$ and soil + foliar application of $\mathrm{ZnS}$ recorded significantly more $\mathrm{K}$ uptake than foliar application of $\mathrm{ZnS}$.

Table 15. Effect of various zinc treatments on $\mathrm{K}$ concentrations of rice kernel, rice husk, rice straw and their uptake in aromatic rice [Meerut, Uttar Pradesh site]

\begin{tabular}{|c|c|c|c|c|c|c|c|}
\hline Treatments & 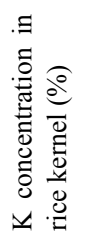 & 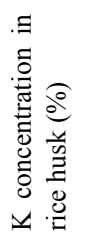 & 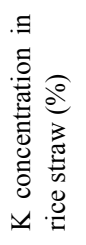 & 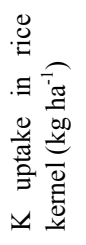 & 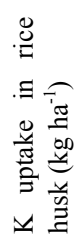 & 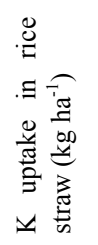 & 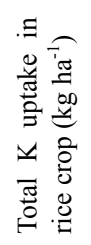 \\
\hline Check & 0.31 & 0.34 & 1.78 & 11.22 & 6.05 & 151.30 & 168.57 \\
\hline $5 \mathrm{~kg} \mathrm{Zn} \mathrm{ha}^{-1}$ (soil) & 0.33 & 0.37 & 1.87 & 12.61 & 6.96 & 166.43 & 186.00 \\
\hline $1 \mathrm{~kg} \mathrm{Zn} \mathrm{ha}^{-1}$ (foliar) & 0.32 & 0.35 & 1.84 & 12.00 & 6.48 & 160.08 & 178.56 \\
\hline $5 \mathrm{~kg} \mathrm{Zn} \mathrm{ha}^{-1}$ (soil) $+1 \mathrm{~kg} \mathrm{Zn} \mathrm{ha}^{-1}$ (foliar) & 0.34 & 0.38 & 1.89 & 13.67 & 7.52 & 173.88 & 195.07 \\
\hline $2.83 \mathrm{~kg} \mathrm{Zn} \mathrm{ha}^{-1}$ through $\mathrm{Zn}$-coated urea (soil) & 0.34 & 0.37 & 1.87 & 12.99 & 6.96 & 168.30 & 188.25 \\
\hline $\mathrm{SEm} \pm$ & 0.007 & 0.009 & 0.013 & 0.39 & 0.21 & 2.59 & 2.92 \\
\hline $\operatorname{LSD}(p=0.05)$ & 0.021 & NS & 0.037 & 1.10 & 0.60 & 7.34 & 8.26 \\
\hline
\end{tabular}




\section{Discussion}

Foliar application of $\mathrm{Zn}$ resulted in higher $\mathrm{Zn}$ concentration in rice kernels than soil application of $\mathrm{ZnS}$ in the on-farm trial in Meerut but not at the Farmers Science Centre in Aligarh. However in both the on-farm trials $\mathrm{Zn}$ concentration in husk was sugnificantly more with foliar than with soil application of Zn. Impa and Johnson-Beebout (2012) reported that biofortification recovery of $\mathrm{Zn}$ with foliar application was 8 times of that obtained with soil application. However data reported by Shivay and Prasad (2010) suggested that $\mathrm{Zn}$ concentration in rice grain was $47.5 \mathrm{mg} \mathrm{kg}^{-1}$, while that in kernel was only $40.3 \mathrm{mg} \mathrm{kg}^{-1}$. Thus more of foliar applied $\mathrm{Zn}$ tended to be retained by the husk. From a study involving multi-country and multi-location trials, Phattrakul et al. (2012) also reported that a major share of foliar applied $\mathrm{Zn}$ was retained in husk.

It needs to be considered that in Asian countries food security is a serious problem alongwith low $\mathrm{Zn}$ concentration in rice (Prasad et al., 2014). In the present study, highest values of yield attributes, rice grain yield and concentrations and uptake of $\mathrm{Zn}, \mathrm{Fe}, \mathrm{N}, \mathrm{P}$ and $\mathrm{K}$ were obtained by soil + foliar application of $\mathrm{Zn}$. This is because soil applied $\mathrm{Zn}$ on $\mathrm{Zn}$ deficient soils results in overall better growth, higher yield attributes and grain and straw yield in rice (Pooniya \& Shivay, 2013), which results in increased uptake of all nutrients. This does not happen with foliar application of $\mathrm{Zn}$, which is made at a much latter stage of crop growth. Soil application of $\mathrm{Zn}$ but not the foliar application of $\mathrm{Zn}$ also resulted in increased crude protein content in rice kernels, which is important from the viewpoint of wide spread protein malnutrition in India and other Asian countries (Prasad, 2003).

For most of the characters studied $\mathrm{ZnCU}$ performed better than $\mathrm{ZnS}$ and was next only to soil + foliar application of $\mathrm{Zn}$. These results are in conformity of our results reported earlier (Shivay et al., 2007, 2008a; Prasad et al., 2013). The major advantage with $\mathrm{ZnCU}$ is saving in the amount of $\mathrm{Zn}$ to be applied; only $2.83 \mathrm{~kg} \mathrm{Zn} \mathrm{ha}{ }^{-1}$ was applied with $\mathrm{ZnCU}$ as against $6 \mathrm{~kg} \mathrm{Zn} \mathrm{ha}^{-1}$ in the case of soil + foliar application of ZnS. The ZnCU is therefore a promising fertilizer.

$\mathrm{Zn}$ application also increased $\mathrm{Fe}, \mathrm{N}, \mathrm{P}$ and $\mathrm{K}$ concentration and uptake in rice. Thus, a soil-foliar $\mathrm{Zn}$ biofortification programme also results in enrichment of rice kernels in $\mathrm{Fe}, \mathrm{N}, \mathrm{P}$ and $\mathrm{K}$. A close relationship between $\mathrm{Zn}, \mathrm{Fe}, \mathrm{N}, \mathrm{P}$ and $\mathrm{K}$ in wheat germplasms has been reported by Gomez-Beccera et al. (2010) and Zhao et al. (2009).

In conclusion, the present study brings out that for increased production of rice alongwith its biofortification with micronutrients $\mathrm{Zn}$ and $\mathrm{Fe}$, adequate soil application of $\mathrm{Zn}$ should be followed by some foliar application of $\mathrm{Zn}$.

\section{Acknowledgements}

The authors are grateful to the Director and Head, Division of Agronomy, Indian Agricultural Research Institute, New Delhi 110 012, India for providing necessary facilities to carry out this research work. Rajendra Prasad is grateful to the Indian National Science Academy for awarding him an Honorary Scientist position, which made this research possible.

\section{References}

Bell, D. W., \& Dell, B. (2008). Micronutrients for sustainable food, feed, fibre and bioenergy products (p. 175). International Fertilizer Industry Association, Paris.

Black, R. E., Lindsay, H. A., Bhutta, Z. A., Caulfield, L. E., DeOnnis, M., Ezzat, M., ... Rivera, J. (2008). Maternal and child under nutrition: Global and regional exposures and health consequences. Lancet, 371, 243-260. http://dx.doi.org/10.1016/S0140-6736(07)61690-0

Gomez, K. A., \& Gomez, A. A. (1984). Statistical Procedures for Agricultural Research. New York: John Wiley $\&$ Sons.

Gomez-Becerra, H. F., Yazici, A., Ozturk, L., Budak, H., Peleg, Z., Morgounov, A., ... Cakmak, I. (2010). Genetic variation and environmental stability of grain mineral nutrient concentrations in Triticum dicoccoides under five environments. Euphytica, 171, 39-52. http://dx.doi.org/10.1007/s10681-009-9987-3

Graham, R. D. (2008). Micronutrient deficiencies in crops and their global significance. In B. J. Alloway (Ed.), Micronutrient deficiencies in global crop production (pp. 41-61). Springer, Dordrecht. http://dx.doi.org/10.1007/978-1-4020-6860-7_2

Hanway, J. J., \& Heidel, H. (1952). Soil analysis methods as used in Iowa State College Soil Testing Laboratory. Bulletin 57. Ames, IA: Iowa State College of Agriculture.

Hotz, C., \& Brown, K. H. (2004). Assessment of the risk of zinc deficiency in populations and options for its 
control. International Zinc Nutrition Consultative Group Technical Document No 1. Food Nutrition Bulletin, 25, S91-S204.

Impa, S. M., \& Johnson-Beebout, S. E. (2012). Mitigating zinc deficiency and achieving high grain Zn in rice through integration of soil chemistry and plant physiology research. Plant and Soil, 361, 3-41. http://dx.doi.org/10.1007/s11104-012-1315-3

Lindsay, W. L., \& Norvell, W. A. (1978). Development of DTPA soil test for zinc, iron, manganese and copper. Soil Science Society of America Journal 42, 428. http://dx.doi.org/10.2136/sssaj1978.03615995004200030009x

Olsen, R., Cole, C. V., Watanabe, F. S., \& Dean, L. A. (1954). Estimation of available phosphorus in soils by extraction with sodium bicarbonate. Circular 939 United States Department of Agriculture. Washington, DC: US Government Printing Office.

Phattarakul, N., Rerkasem, B., Li, L. J., Wu, L. H., Zou, C. Q., Ram, H., ... Cakmak, I. (2012). Biofortification of rice grain with zinc through zinc fertilization in different countries. Plant and Soil, 361, 131-141. http://dx.doi.org/10.1007/s11104-012-1211-x

Pooniya, V., \& Shivay, Y. S. (2013). Enrichment of Basmati rice grain and straw with zinc and nitrogen through ferti-fortification and summer green manuring under Indo-Gangetic plains of India. Journal of Plant Nutrition, 36(1), 91-117. http://dx.doi.org/10.1080/01904167.2012.733052

Prasad, R. (2003). Protein-energy malnutrition in India. Fertiliser News, 48(4), 13-26.

Prasad, R. (2006). Zinc in soils and in plant, human and animal nutrition. Indian Journal of Fertilizers, 2 , 103-119.

Prasad, R., \& Power, J. F. (1997). Soil Fertility Management for Sustainable Agriculture (p. 356). Boca Raton, New York: CRC, Lewis Publishers.

Prasad, R., Shivay, Y. S., \& Kumar, D. (2013). Zinc fertilization of cereals for increased production and alleviation of zinc malnutrition in India. Agricultural Research, 2(2), 111-118. http://dx.doi.org/10.1007/s40003-013-0064-8

Prasad, R., Shivay, Y. S., \& Kumar, D. (2014). Agronomic biofortification of cereal grains with iron and zinc. Advances in Agronomy, 125, 55-91. http://dx.doi.org/10.1016/B978-0-12-800137-0.00002-9

Prasad, R., Shivay, Y. S., Kumar, D., \& Sharma, S. N. (2006). Learning by Doing Exercises in Soil Fertility (A Practical Manual for Soil Fertility) (pp. 68). Division of Agronomy, Indian Agricultural Research Institute, New Delhi.

Rani, N. S., Prasad, G. S. V., \& Viraktamath, B. C. (2009). National system for evaluation of Basmati rices for yield and quality traits. Indian Farming, 59, 7-11.

Shivay, Y. S., \& Prasad, R. (2012). Zinc-coated urea improves productivity and quality of Basmati rice (Oryza sativa L.) under zinc stress condition. Journal of Plant Nutrition, 35, 928-951. http://dx.doi.org/10.1080/01904167.2012.663444

Shivay, Y. S., \& Prasad, R. (2014). Effect of source and methods of zinc application on corn productivity, nitrogen and zinc concentrations and uptake by high quality protein corn (Zea mays). Egyptian Journal of Biology, 16(1), 72-78. http://dx.doi.org/10.4314/ejb.v16i1.10

Shivay, Y. S., Kumar, D., \& Prasad, R. (2008a). Effect of zinc-enriched urea on productivity, zinc uptake and efficiency of an aromatic rice-wheat cropping system. Nutrient Cycling in Agroecosystems, 81(3), 229-243. http://dx.doi.org/10.1007/s10705-007-9159-6

Shivay, Y. S., Kumar, D., \& Prasad, R. (2008c). Relative efficiency of zinc sulphate and zinc oxide coated urea in rice-wheat cropping system. Communication in Soil Science and Plant Analysis, 39, 1154-1167. http://dx.doi.org/10.1080/00103620801925869

Shivay, Y. S., Kumar, D., Ahlawat, I. P. S., \& Prasad, R. (2007). Relative efficiency of zinc oxide and zinc sulfate coated urea for rice. Indian Journal of Fertilizers, 3(2), 51-56.

Shivay, Y. S., Prasad, R., \& Rahal, A. (2008b). Relative efficieny of zinc oxide and zinc sulphate enriched urea for spring wheat. Nutrient Cycling in Agroecosystems, 82, 259-264. http://dx.doi.org/10.1007/s10705-008-9186-y

Shivay, Y. S., Prasad, R., \& Rahal, A. (2010). Genotypic variation for productivity, zinc utilization efficiencies, 
and kernel quality in aromatic rices under low available zinc conditions. Journal of Plant Nutrition, 33, 1835-1848. http://dx.doi.org/10.1080/01904167.2010.503832

Shivay, Y. S., Prasad, R., \& Pal, M. (2013). Zinc fortification of oats grain and straw through zinc fertilization. Agricultural Research, 2, 375-381. http://dx.doi.org/10.1007/s40003-013-0078-2

Siddiq, E. A., Vemireddy, L. R., \& Nagraju, J. (2012). Basmati rices: Genetics, breeding and trade. Agricultural Research, 1, 25-36. http://dx.doi.org/10.1007/s40003-011-0011-5

Singh, M. V. (2011). Assessing extent of zinc deficiency for soil factors affecting and nutritional scarcity in humans and animals. Indian Journal of Fertiliser, 7(10), 36-43.

Singh, V. P., \& Singh, A. K. (2009). History of Basmati rice research and development in India. Indian Farming, 59, 4-6.

Stein, A. J., Nestel, P., Meenakshi, J. V., Qaim, M., Sachdev, H. P. S., \& Bhutta, Z. (2007). Plant breeding to control zinc deficiency in India: How cost effective is biofortification? Public Health Nutrition, 10, 492-501. http://dx.doi.org/10.1017/S1368980007223857

Subbiah, B. V., \& Asija, G. L. (1956). A rapid procedure for the determination of available nitrogen in soils. Current Science, 25, 259-260.

Takkar, P. N., Singh, M. V., \& Ganeshmurthy, A. N. (1997). A critical review of plant nutrient supply needs, efficiency and policy issues for Indian agriculture for the year 2000: Micronutrients and Trace elements. In J. S. Kanwar \& J. C. Katyal (Eds.), Plant Nutrient, Supply Efficiency and Policy Issues: $2000-2025$ (pp. 238-264). New Delhi: National Academy of Agricultural Sciences.

Walkley, A. J., \& Black, I. A. (1934). An examination of the Degtjareff method for determination soil organic matter and a proposed modification of the chromic acid titration method. Soil Science, 37, $29-38$. http://dx.doi.org/10.1097/00010694-193401000-00003

Welch, R. M. (2005). Harvesting health: agricultural linkages for improving human nutrition. In P. Anderson, J. K. Tuladhada, K. B. Karki \& S. L. Maskey (Eds.), Micronutrients in south and Southeast Asia (pp. 9-10). International Centre for Integrated Mountain Development, Kathmandu.

Zhao, F. J., Su, Y. H., Dunham, S. J., Rakszegi, M., Bedo, Z., McGrath, S. P., \& Shewry, P. R. (2009). Variation in mineral micronutrient concentrations in grain of wheat lines of diverse origin. Journal of Cereal Science, 49, 290-295. http://dx.doi.org/10.1016/j.jcs

\section{Copyrights}

Copyright for this article is retained by the author(s), with first publication rights granted to the journal.

This is an open-access article distributed under the terms and conditions of the Creative Commons Attribution license (http://creativecommons.org/licenses/by/3.0/). 